\title{
Status of Taal Lake Fishery Resources with Emphasis on the Endemic Freshwater Sardine, Sardinella tawilis (Herre, 1927)
}

\author{
Maria Theresa M. Mutia ${ }^{1, \star}$, Myla C. Muyot ${ }^{1,}$, Francisco B. Torres Jr. ${ }^{1}$, Charice M. Faminialagao ${ }^{1}$ \\ ${ }^{1}$ National Fisheries Research and Development Institute, 101 Corporate Bldg., Mother Ignacia St., South Triangle, \\ Quezon City
}

\section{A B S T R A C T}

Assessment of fisheries in Taal Lake was conducted from 1996-2000 and 2008-2011 to know the status of the commercially important fishes with emphasis on the endemic freshwater sardine, Sardinella tawilis. Results of the fish landed catch survey in 11 coastal towns of the lake showed a decreasing fish harvest in the open fisheries from 1,420 MT to $460 \mathrm{MT}$ in 1996 to 2011. Inventory of fisherfolk, boat, and gear also decreased to $16 \%, 7 \%$, and $39 \%$, respectively from 1998 to 2011 . The most dominant gear is gill net which is about $53 \%$ of the total gear used in the lake with a declining catch per unit effort (CPUE) of $11 \mathrm{~kg} /$ day to $4 \mathrm{~kg} / \mathrm{day}$ from 1997 to 2011. Active gear such as motorized push net, ring net, and beach seine also operated in the lake with a CPUE ranging from $48 \mathrm{~kg} /$ day to $2,504 \mathrm{~kg} /$ day. There were 43 fish species identified in which $S$. tawilis dominated the catch for the last decade. However, its harvest also declined from 744 to $71 \mathrm{mt}$ in 1996 to 2011. The presence of alien species such as jaguar fish, pangasius, and black-chinned tilapia amplified in 2009.

Population parameters of S. tawilis from 2009 to 2011 were estimated using the FiSAT (FAO-ICLARM Stock Assessment Tool) software. The analysis of length frequency data showed an estimated $\mathrm{L}_{\infty}$ of 15.40 to 16.36 $\mathrm{cm}$ and $\mathrm{K}$ value ranged from 0.53 to 0.73 . The total mortality $(\mathrm{Z})$ ranged from 3.01 to 5.03 , natural mortality (M) from 1.44 to 1.75 , fishing mortality (F) from 1.57 to 3.28 and exploitation rate (E) from 0.52 to 0.65 . The high values of fishing mortality and exploitation rates indicate unsustainable fishing practices. Conservation and management measures of the fishery resources in the lake were recommended for appropriate action of the Protected Area Management Board (PAMB).

*E-mail: tmmutia@yahoo.com

Keywords: Taal Lake, Sardinella tawilis,

Received: 23 March 2017 fisheries, population parameters

Accepted: 29 September 2017

\section{INTRODUCT I ON}

L aal Lake is the 3rd largest lake in the country with an area of 24,356.4 ha and bounded by nine towns and two cities. In its center lies the 23.8 $\mathrm{km}^{2}$ Volcano Island which has a $1.9 \mathrm{~km}$ crater lake in the middle. The lake is very deep with a maximum depth of $180 \mathrm{~m}$ and an average depth of $65 \mathrm{~m}$. There are 38 tributary rivers draining into the lake, some of which are spring waters in origin. Located in the southern portion of the lake is the $8.2 \mathrm{~km}$ Pansipit River which is the only drainage of the lake that empties into Balayan Bay. The lake has multiple-resource use and its dominant use is fisheries of which aquaculture has flourished rapidly over the years. The resource is also used for recreation, tourism, navigation, water source for Tagaytay and for agricultural fields, and source of feeds for ducks.

The lake fisheries provide livelihood to around 2,761 sustenance fisherfolk (BFAR 1998) who gather finfishes, crustaceans, and mollusks found in commercial quantities in the lake. Total fish production slowly declined from 8,792 MT in 1992 (Aypa 1993) to $882 \mathrm{MT}$ in 2000 (Mutia 2004). Fish production of the open water fisheries has dwindled over the years as shown by the continuous decline of fish caught by the fishermen. This may be attributed to illegal fishing, overfishing, pollution and the expansion of aquaculture activities in the lake.

Published literature on Taal Lake fisheries were very limited. A Rapid Resource Appraisal of Taal Lake was conducted by UPLB-FI in 1996. Status of freshwater fishes in major lakes was studied by Mercene in 1997. Villanueva et al (1996) determined the status of Taal Lake capture fisheries and the extent of exploitation of $S$. tawilis. Mutia et al (2004) reported a declining production of tawilis from $744 \mathrm{MT}$ in 1996 to $294 \mathrm{MT}$ in 2000 due to illegal operation of active gear (motorized push net and ring net) and pollution load contributed by improper aquaculture practices.

This paper aims to provide a reliable data on the present status of fishery resources in Taal Lake and recommend appropriate policy regulations on its conservation and management. Specifically, it aims to 1) make an inventory of fisherfolk, boat and gear, 2) know the catch and species composition, 3) provide estimates of fish harvests in the open water fisheries, 4) catch and effort of major gear and 5) provide estimates on growth, mortality and exploitation rates of Sardinella tawilis. 


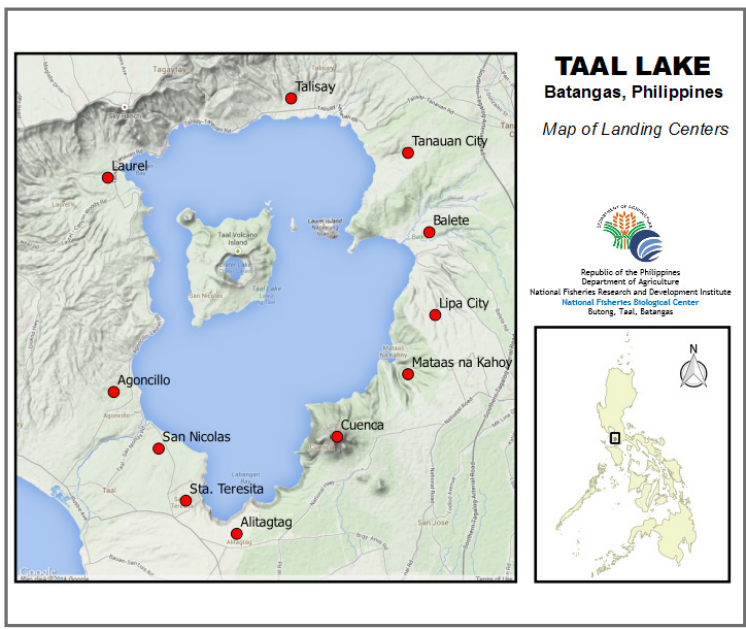

Figure 1. Location map of landing centers in Taal Lake.

\section{METHOD OLOG Y}

\section{Landing centers/ sampling sites}

The sampling stations were established in the fish landing sites of the eleven coastal towns of Taal Lake, namely Alitagtag, Agoncillo, San Nicolas, Sta. Teresita, Balete, Laurel, Tanauan, Lipa, Cuenca, Talisay and Mataas na Kahoy (Figure 1).

\section{Data collection}

Data on the number of fisherfolk, fishing boat and gear were collected and recorded by the enumerators from the fisherfolk registry of the Municipal Fisheries and Aquatic Resource Management Council (MFARMC) and the Office of the Municipal Agriculturist (MAO). The actual enumeration was also done to validate the records.

Fish landed catch survey was conducted by trained fisherfolk enumerators using a standard survey form on catch and effort. The survey was done in 2 days interval or a total of 20 days in a month including Saturdays, Sundays and Holidays. The survey form includes the following data gathered: landing site, fishing ground, volume of catch per species, type and number of gear and boat used, number of hours fishing, and number of people included in the fishing operation. All survey forms were submitted monthly for collation and processing.

\section{Data analysis}

\section{Catch and species composition}

The species composition caught by all gear in the lake were listed and identified up to species level. The fishery resources were categorized into fish, invertebrates and other organisms. These species were classified into endemic, introduced and migratory species. Total catch of each species by gear for the year was computed and ranked from highest to lowest. Percentage composition of the major species from the total fish production was determined.

\section{Production estimates}

Fish production was estimated by extrapolation. Total catch for the day in kilograms (TCD) was computed by multiplying the total catch for the day $(\mathrm{C})$ to a raising factor (RF) equivalent to the number sampled landings over total landings for the day. Monthly and annual productions were computed by raising the total catch for the day. Hereunder are the following computations:

(1) Total catch for the day (TCD) = Catch for the day $(\mathrm{C}) \mathrm{x}$ raising factor (RF)

where: $\mathrm{RF}=$ number of total landing/sampled landings

(2) Total catch for the month $(\mathrm{TCM})=\mathrm{TCD} \times \mathrm{RF}$ where: $\mathrm{RF}=$ number of days in a month/sampled days

(3) Total catch for the year (TCY) $=$ TCM $x$ RF where: RF =number of months in a year/ sampled months

\section{Catch per unit effort}

The different fishing gear used in the lake were identified and catch compositions by each gear were determined. The catch per unit effort (CPUE) of each gear was determined using a standardized unit of effort such as kilogram per day (kg/day). The CPUE is computed by taking the average catch for the day per gear. The annual mean CPUE was obtained by the summation of the monthly fish harvest over the summation of the number of fishing days in a month/year.

\section{Population parameters}

The analysis of length frequency data of $S$. tawilis was done. The total length (TL) of about 200-300 fish samples per month were measured to record length frequency data. The data were run using the FAO-ICLARM Stock Assessment Tool or FiSAT II version 1.2.2 software (Gayanilao et al. 1997). Powell Wetherall Plot was used in estimating the parameters $\mathrm{L}_{\infty}$ (asymptotic length) and ELEFAN I was used to estimate $\mathrm{K}$ (curvature parameter) of growth formula while mortalities were estimated as the total mortality $(\mathrm{Z})$ via catch curve method, natural mortality (M) using built-in empirical equation and fishing mortality $(\mathrm{F})$ by getting the difference between $\mathrm{Z}$ and $\mathrm{M}$. The exploitation ratio $(\mathrm{E}=\mathrm{F} / \mathrm{Z})$ of the fish were derived using computed mortalities.

\section{RES U L T S}

Fisherfolk, fishing boat and gear inventory 
Table 1. Number of fisherfolk by municipality in Taal Lake

\begin{tabular}{ccccc}
\hline Town & No. Coastal Barangay & \multicolumn{3}{c}{ Number of Fisherfolk } \\
\hline & & $\mathbf{1 9 9 8}$ & $\mathbf{2 0 0 9}$ & $\mathbf{2 0 1 1}$ \\
\hline Agoncillo & 11 & 916 & 215 & 189 \\
Alitagtag & 10 & 22 & 71 & 72 \\
Balete & 6 & 89 & 246 & 132 \\
Cuenca & 1 & 89 & 89 & 107 \\
Laurel & 8 & 653 & 511 & 525 \\
Lipa City & 1 & 20 & 80 & 44 \\
Mataas na Kahoy & 3 & 91 & 119 & 123 \\
San Nicolas & 12 & 704 & 800 & 700 \\
Sta. Teresita & 3 & 60 & 68 & 30 \\
Tanauan City & 6 & 84 & 628 & 287 \\
Talisay & 11 & 33 & 133 & 102 \\
\hline TOTAL & $\mathbf{7 2}$ & $\mathbf{2 7 6 1}$ & $\mathbf{2 9 6 0}$ & $\mathbf{2 3 1 1}$ \\
\hline
\end{tabular}

Table 2. Number of fishing boat by municipality in Taal Lake

\begin{tabular}{|c|c|c|c|c|c|c|c|}
\hline \multirow[b]{3}{*}{$\begin{array}{c}\text { Coastal } \\
\text { Municipality }\end{array}$} & \multicolumn{7}{|c|}{ Number of Boat } \\
\hline & \multicolumn{2}{|c|}{1998} & \multicolumn{2}{|c|}{2009} & \multicolumn{3}{|c|}{2011} \\
\hline & $\begin{array}{c}\text { Motorized } \\
\text { Boat }\end{array}$ & $\begin{array}{c}\text { Non-Motor- } \\
\text { ized Boat }\end{array}$ & $\begin{array}{c}\text { Motorized } \\
\text { Boat }\end{array}$ & $\begin{array}{l}\text { Non-Motor- } \\
\text { ized Boat }\end{array}$ & $\begin{array}{c}\text { Motorized } \\
\text { Boat }\end{array}$ & $\begin{array}{l}\text { Non-motor- } \\
\text { ized Boat }\end{array}$ & Raft \\
\hline Agoncillo & 124 & 618 & 47 & 74 & 57 & 33 & 26 \\
\hline Alitagtag & 5 & 45 & 16 & 42 & 16 & 20 & 41 \\
\hline Balete & 83 & 21 & 87 & 43 & 87 & 4 & 19 \\
\hline Cuenca & 92 & 16 & 81 & 18 & 81 & 0 & 6 \\
\hline Laurel & 116 & 317 & 203 & 136 & 203 & 0 & 26 \\
\hline Lipa & 20 & 15 & 29 & 15 & 29 & 13 & 26 \\
\hline Mataas na Kahoy & 61 & 12 & - & 58 & 92 & 13 & 5 \\
\hline San Nicolas & 250 & 450 & 373 & 565 & 373 & 43 & 0 \\
\hline Sta. Teresita & 25 & 55 & 24 & 60 & 24 & 4 & 20 \\
\hline Tanauan & 24 & 33 & 96 & 139 & 96 & 34 & 5 \\
\hline \multirow[t]{2}{*}{ Talisay } & 50 & 15 & 52 & 32 & 52 & 4 & 32 \\
\hline & 850 & 1597 & 1008 & 1182 & 1110 & 168 & 206 \\
\hline Total & \multicolumn{2}{|c|}{2,447} & \multicolumn{2}{|c|}{2,190} & \multicolumn{3}{|c|}{1,484} \\
\hline
\end{tabular}

There are 9 towns and 2 cities with 72 coastal barangays surrounding Taal Lake. The number of fisherfolk for the past 14 years declined from 2,761 to 2,311 (1998-2011). The latest record in 2011 showed that the highest number of fisherfolk was from the municipality of San Nicolas while the least number of fisherfolk was from Sta. Teresita (Figure 2 and Table 1). On the other hand, the number of fishing boat also decreased to about $7 \%$ or from 2,447 units to 1,484 boats operating in the lake, of which 1,110 were motorized, 168 non-motorized and 206 bamboo raft (Table 2 and Figure 3).

Fishing gear inventory in 2011 recorded a total of 2,375 units of 15 different types of fishing gear used in the lake (Table 3). These include gillnet, beach seine, fish corral, push net, hook and line, fish trap, scoop net, rake, spear gun, lift net, ring net, motorized push net, bamboo fish trap, fish spear, and cover net. The most number of gear is gill net with 1,258 units or $52.8 \%$ of the total number of gear in the lake (Figure 4 and Table 3). Other dominant gears were bamboo fish trap (16.8\%), fish trap (15.7\%), spear gun (5.5\%), and hook and line (4.12\%). Among the 15 gear identified, there were 3 active gear present in the lake, namely motorized push net, ring net, and beach seine. Although prohibited in the lake, these active gear were observed to have fish catch landings in

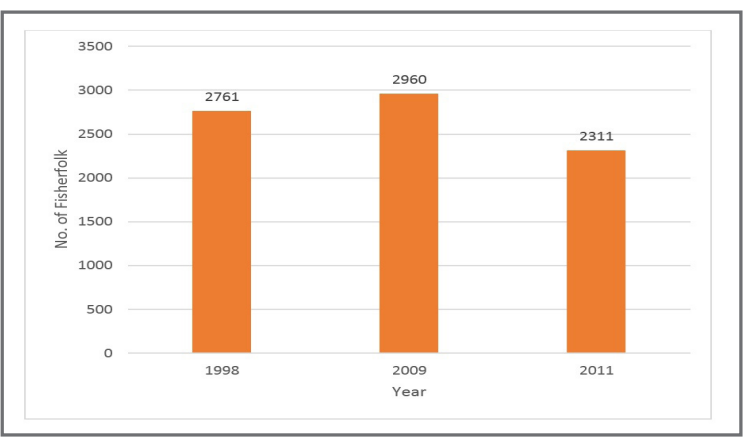

Figure 2. Number of fisherfolk in Taal Lake

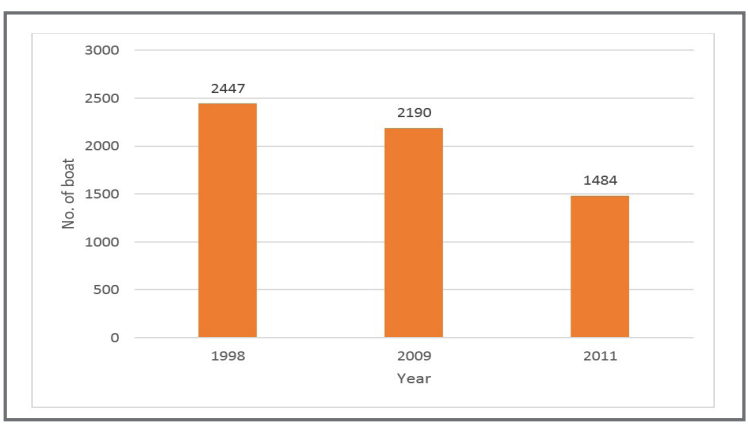

Figure 3. Number of boat in Taal Lake 
Table 3. Number of fishing gear by municipality in Taal Lake

\begin{tabular}{lccc}
\hline \multirow{2}{*}{ Gear } & \multicolumn{3}{c}{ Number of gear } \\
\cline { 2 - 4 } & $\mathbf{1 9 9 8}$ & $\mathbf{2 0 0 9}$ & $\mathbf{2 0 1 1}$ \\
\hline Gill net (pante) & 1616 & 1,770 & 1,258 \\
Spear gun (pana) & 237 & 291 & 132 \\
Hook \& Line (Kawil) & 165 & 554 & 97 \\
Fish trap (bubo) & 253 & 250 & 375 \\
Fish corral (baklad) & 91 & 1 & 11 \\
Lift net (pantaas) & 49 & - & 1 \\
Beach seine (pukot) & 38 & 38 & 40 \\
Scissors net (salap) & 24 & - & - \\
Crab lift net (bintol) & 25 & - & - \\
Motorized push net (suro) & 15 & 17 & 17 \\
Ring net (basnig) & 15 & 7 & 4 \\
Cover pot (saklob) & 10 & - & 5 \\
Fish shelter (paksol) & 5 & - & - \\
Drive-in net (sakag/paksol) & 23 & - & - \\
Bamboo fish trap (tukil) & - & - & 401 \\
Scoop net (sigpaw) & - & - & 8 \\
Fish spear (salapang) & - & - & 3 \\
Rake (balukay) & - & - & 23 \\
Cast net (dala) & - & 5 & - \\
\hline \multicolumn{1}{c}{$\mathbf{1 9}$ gear } & $\mathbf{2 , 5 6 6}$ & $\mathbf{2 , 9 3 3}$ & $\mathbf{2 , 3 7 5}$ \\
\hline
\end{tabular}

the lake.

\section{Catch/Species composition}

A total of 52 species were caught at the different landing centers in the Taal Lake from 1996 to 2011. The species composition was comprised of 43 finfishes and 4 crustaceans, 3 mollusks and 2 reptiles belonging to 30 families (Table 4). Of the finfishes caught, 1 was endemic, 2 natives, 14 introduced, and 26 migratory species (Table $5)$.

The three endemic/native fishes recorded are Sardinella tawilis, Glossogobius giuris, and Channa striata. Introduced species were observed to increase in production starting 2009. A new record of introduced or alien species include Parachromis managuensis (jaguar guapote), Pangasianodon hypopthalmus (pangasius), Colossoma macropomum (red-bellied pacu), Ptergoplichthys disjunctivus (janitor fish), and Sarotherodon melanotheron (black-chinned tilapia). These species were not present in the previous assessment from 1996 to 2000. The introduction of janitor fish, jaguar guapote, red pacu and black-chinned tilapia were suspected to be unintentional and some unknown. However, pangasius was intended for aquaculture and its presence in the open waters was due to its escapement in cages during the strong typhoon in 2008. Migratory fishes were observed to increase in number in 2010-2011. This can be attributed to the clearance of Pansipit River from fish cages and fish corrals which allowed the different species from Balayan Bay to migrate to the lake.

Crustaceans, mollusks, and reptiles were also present in the landed catch survey. Four species of crustaceans, 3 species of mollusks, and 2 species of reptiles were recorded (Table 4). Among them, white

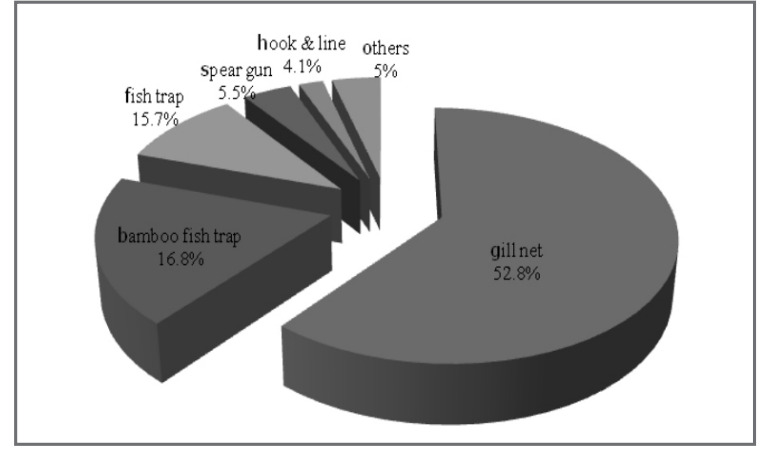

Figure 4. Percentage composition of major fishing gear in the lake

shrimp or hipong puti and freshwater clam or tulya/peras were caught in large quantities for human consumption only and sometimes for animal feed.

\section{Total fish harvest estimates}

Figure 5 shows the estimated total fish harvest in the open water fisheries of Taal Lake. There was an increasing fish harvest from 1,420 to $1,672 \mathrm{MT}$ in 1996 to 1998, however, fish harvest declined to $460 \mathrm{MT}$ in 2011. On the contrary, aquaculture production flourished from 3,140 to 6,000 cages from 1996 to 2010 (Municipal Agriculture Office) with an estimated production of 23,000 MT to 79,000 MT in 2001 to 2010 (BAS 2011).

\section{Tawilis harvest estimates}

Tawilis harvest increased from $744 \mathrm{MT}$ to 1,120 MT in 1996 to 1998, however, suddenly declined to 674 MT in 1999. Tawilis harvest continued to decline up to 
Table 4. Species composition of landed catch.

\begin{tabular}{|c|c|c|c|c|c|}
\hline No. & Scientific name & Family & English name & Local name & Classification \\
\hline & FINFISHES & & & & \\
\hline 1 & Sardinella tawilis & Clupeidae & Freshwater sardine & Tawilis & $\mathrm{E}$ \\
\hline 2 & Oreochromis niloticus & Cichlidae & Nile tilapia & Tilapia & I \\
\hline 3 & Atherinomorus lacunosus & Atherinidae & $\begin{array}{l}\text { Wide-banded } \\
\text { Hardyhead } \\
\text { Silverside }\end{array}$ & Guno & M \\
\hline 4 & Chanos chanos & Channidae & Milkfish & Bangus & $\mathrm{M}$ \\
\hline 5 & Caranx ignobilis & Carangidae & Giant trevally & Maliputo & M \\
\hline 6 & Carassius auratus & Cyprinidae & Carp & Karpita & I \\
\hline 7 & Glossogobius giuris & Gobiidae & Tank goby & Bia & $\mathrm{N}$ \\
\hline 8 & Leiopotherapon plumbeus & Terapontidae & Silver perch & Ayungin & I \\
\hline 9 & Pangasianodon hypopthalmus & Pangasiidae & Iridescent shark & Pangasius & I \\
\hline 10 & Ostorhinchus thermalis & Apogonidae & $\begin{array}{l}\text { Half-barred } \\
\text { Cardinal fish }\end{array}$ & Dangat & M \\
\hline 11 & Apogon hyalosoma & Apogonidae & $\begin{array}{l}\text { Humpbacked } \\
\text { cardinal fish }\end{array}$ & Muang & M \\
\hline 12 & Parachromis managuensis & Cichlidae & Jaguar guapote & Dugong & I \\
\hline 13 & Anguilla marmorata & Anguillidae & Giant mottled eel & Igat & M \\
\hline 14 & Channa striata & Channidae & Striped snakehead & Dalag & $\mathrm{N}$ \\
\hline 15 & Glossogobius celebius & Gobiidae & Celebes goby & $\begin{array}{l}\text { Pauto/Biyang } \\
\text { tulog }\end{array}$ & M \\
\hline 16 & Caranx sexfasciatus & Carangidae & Bigeye trevally & Muslo & M \\
\hline 17 & Giuris margaritacea & Eleotridae & Snakehead gudgeon & Palawon & M \\
\hline 18 & Carassius carassius & Cyprinidae & Crusian Carp & Karpita & $\mathrm{I}$ \\
\hline 19 & Toxotes jaculatrix & Toxotidae & Banded Archerfish & Kataba & M \\
\hline 20 & Clarias batrachus & Clariidae & Philippine catfish & Hito & I \\
\hline 21 & Lutjanus argentimaculatus & Lutjanidae & $\begin{array}{c}\text { Mangrove red } \\
\text { snapper }\end{array}$ & Also & M \\
\hline 22 & Hypophthalmichthys nobilis & Cyprinidae & Bighead carp & Bighead carp & I \\
\hline 23 & Scatophagus argus & Scatophagidae & Spadefish & Kitang & M \\
\hline 24 & Mugil cephalus & Mugilidae & $\begin{array}{c}\text { Flathead grey } \\
\text { mullet }\end{array}$ & Banak & M \\
\hline 25 & Megalops cyprinoides & Megalopidae & Indo-Pacific Tarpon & Buan-buan & M \\
\hline 26 & Lutjanus malabaricus & Lutjanidae & $\begin{array}{c}\text { Malabar red } \\
\text { snapper }\end{array}$ & Maya-maya & M \\
\hline 27 & Ambassis miops & Ambassidae & Flag-tailed glassfish & Ning-ning & M \\
\hline 28 & Ctenopharyngodon idella & Cyprinidae & Grasscarp & Karp & $\mathrm{I}$ \\
\hline 29 & Caranx sp. & Carangidae & Cavalla & Pepikat & M \\
\hline 30 & Sarotherodon melanotheron & Cichlidae & Black chin tilapia & $\begin{array}{l}\text { Tilapiang } \\
\text { arroyo }\end{array}$ & I \\
\hline 31 & Hyporhamphus quoyi & Hemiramphidae & Quoy's garfish & Siliw & M \\
\hline 32 & Zenarchopterus buffonis & Zenarchopteridae & $\begin{array}{l}\text { Buffon's river- } \\
\text { garfish }\end{array}$ & Siliw & M \\
\hline 33 & Caranx sp. & Carangidae & Cavalla & Karis-karis & M \\
\hline 34 & Acentrogobius suluensis & Gobiidae & Sharptail goby & Tunghod & M \\
\hline 35 & $\begin{array}{l}\text { Oreochromis niloticus } \times O \text {. } \\
\text { hornorum }\end{array}$ & Cichlidae & Red tilapia & Red Tilapia & I \\
\hline 36 & Elops machnata & Elopidae & Tenpounder & $\begin{array}{l}\text { Kanoping/ } \\
\text { Bidbid }\end{array}$ & M \\
\hline 37 & Colossoma macropomum & Serrasalmidae & Cachama & Pacu & I \\
\hline 38 & Chelon melinepterus & Mugilidae & Otomebora Mullet & Aligasin & M \\
\hline 39 & Pterygoplichthys disjunctivus & Loricariidae & Spotted catfish & Janitor fish & I \\
\hline 40 & Gerres filamentosus & Gerreidae & $\begin{array}{l}\text { Whipfin silver } \\
\text { biddy }\end{array}$ & Balabatuhan & M \\
\hline 41 & Trichopodus trichopterus & Osphronemidae & $\begin{array}{l}\text { Three spot } \\
\text { Gourami }\end{array}$ & Gourami & I \\
\hline 42 & Terapon jarbua & Terapontidae & Convex-lined grunt & Bagaong & M \\
\hline 43 & $\begin{array}{l}\text { Lates calcarifer } \\
\text { Others } \\
\text { Crustacean }\end{array}$ & Latidae & Giant seaperch & Apahap & M \\
\hline
\end{tabular}




\begin{tabular}{|c|c|c|c|c|c|}
\hline No. & Scientific name & Family & English name & Local name & Classification \\
\hline 44 & Macrobrachium sp. & & White shrimp & Hipon & \\
\hline 45 & Atya $s p$. & & Atyid prawn & Apta & \\
\hline 46 & Potamon sp. & & & Katang & \\
\hline 47 & $\begin{array}{l}\text { Macrobrachium sp. } \\
\text { Molluscs }\end{array}$ & & Freshwater prawn & Ulang & \\
\hline 48 & Cristaria plicata & & Freshwater clam & Peras & \\
\hline 49 & Melania blatta & & & Suso & \\
\hline 50 & Pomacea canaliculata & & Golden apple snail & $\begin{array}{c}\text { Kuhol/sihe } \\
\text { Parus }\end{array}$ & \\
\hline & Reptile & & & & \\
\hline 51 & Pelodiscus sinensis & & Soft shelled turtle & Pawikan & \\
\hline 52 & Hydrophis semperi & & Seasnake & Dohol & $\mathrm{E}$ \\
\hline
\end{tabular}

Table 5. Endemic, introduced, migratory species in Taal Lake

\begin{tabular}{cccccc}
\hline Year & Endemic & Introduced & Migratory & Total & Source \\
\hline 1997 & 5 & 4 & 16 & 25 & Villanueva 1996 \\
2000 & 4 & 6 & 16 & 27 & Mutia, et al 2004 \\
2009 & 3 & 6 & 17 & 27 & Mutia, et al 2011 \\
2010 & 3 & 10 & 23 & 37 & Mutia, et al 2011 \\
2011 & 3 & 14 & 26 & 42 & Mutia, et al 2011 \\
\hline
\end{tabular}

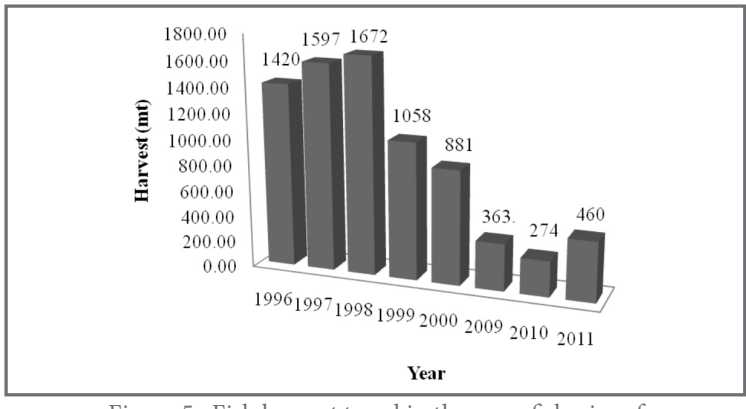

Figure 5. Fish harvest trend in the open fisheries of Taal Lake.

71 MT in 2011 or about $89 \%$ reduction in 12 years.

\section{Dominant species}

The top 10 major fish species caught in the lake from 1996-2000 and 2009-2011 are as follows: Sardinella tawilis, Oreochromis niloticus, Atherinomorus lacunosus, Chanos chanos, Caranx ignobilis, Carassius auratus, Glossogobius giuris, Leiopotherapon plumbeus, Pangasianodon hypopthalmus, and Ostorhinchus thermalis (Figure 7). S. tawilis has been consistently the most dominant species in the open water fisheries, however, in 2011 P. hypopthalmus dominated the catch with 148 MT.

\section{Catch per unit effort}

The catch per unit effort (CPUE) of the major fishing gear in the lake is shown in Table 6. The active gear such as ring net, motorized push net, and beach seine have the highest CPUE. These gear are prohibited to operate in the lake. The CPUE of ring net increased tremendously from 143 to $2,504 \mathrm{~kg} /$ day from 1997 to 2011. CPUE of motorized push net and beach seine

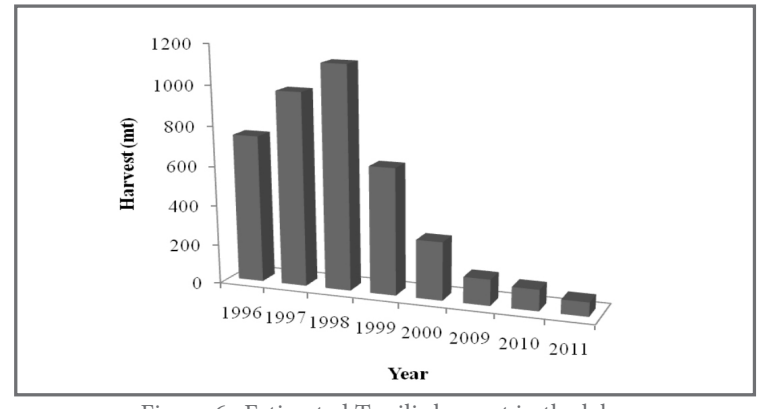

Figure 6. Estimated Tawilis harvest in the lake.

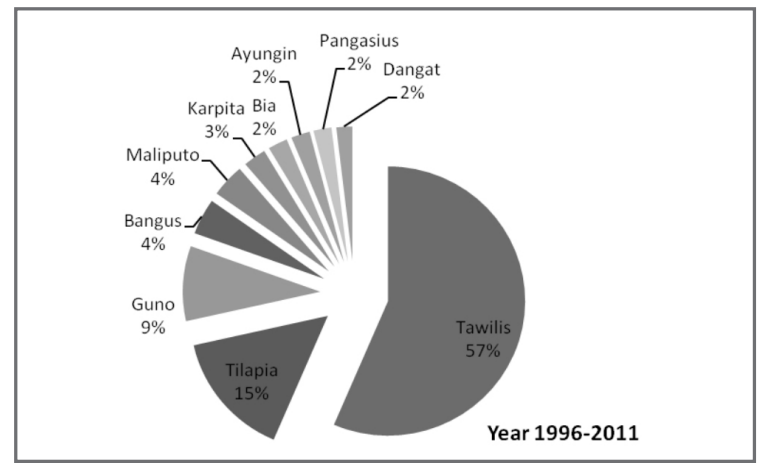

Figure 7. Dominant species in Taal Lake

continued to increase in the past 14 years. However, the CPUE of gill net which is the most dominant passive gear continued to decline from $11 \mathrm{~kg} /$ day to $4.4 \mathrm{~kg} /$ day in 1997 to 2011 .

Despite the effort to fish in both active and passive gear, the fish harvest remained to decline especially the endemic freshwater sardine and all other 
Table 6. Catch per unit effort ( $\mathrm{kg} /$ day) by gear in Taal Lake, Batangas from 1997-2000 \& 2010.

\begin{tabular}{llcccccc}
\hline Fishing Gear & Local Name & $\mathbf{1 9 9 7}$ & $\mathbf{1 9 9 8}$ & $\mathbf{1 9 9 9}$ & $\mathbf{2 0 0 0}$ & $\mathbf{2 0 1 0}$ & $\mathbf{2 0 1 1}$ \\
\hline Gill net & Pante & 11 & 12 & 6 & 8 & 6.6 & 4.4 \\
Beach seine & Pukot & 48 & 68 & 66 & 34 & 25.6 & 72.9 \\
Ring net & Pangulong/basing & 143 & 276 & 43 & - & 30 & 2504.5 \\
M.push net & Suro & 379 & 327 & 168 & 111 & 544.3 & 222.2 \\
\hline
\end{tabular}

Table 7. Tawilis population parameters

\begin{tabular}{ccccccc}
\hline Year & L $\infty$ & K & Z & M & F & E \\
\hline 2009 & 15.40 & 0.53 & 3.01 & 1.44 & 1.57 & 0.52 \\
2010 & 16.36 & 0.73 & 5.03 & 1.75 & 3.28 & 0.65 \\
2011 & 15.76 & 0.63 & 3.55 & 1.61 & 1.94 & 0.55 \\
\hline
\end{tabular}

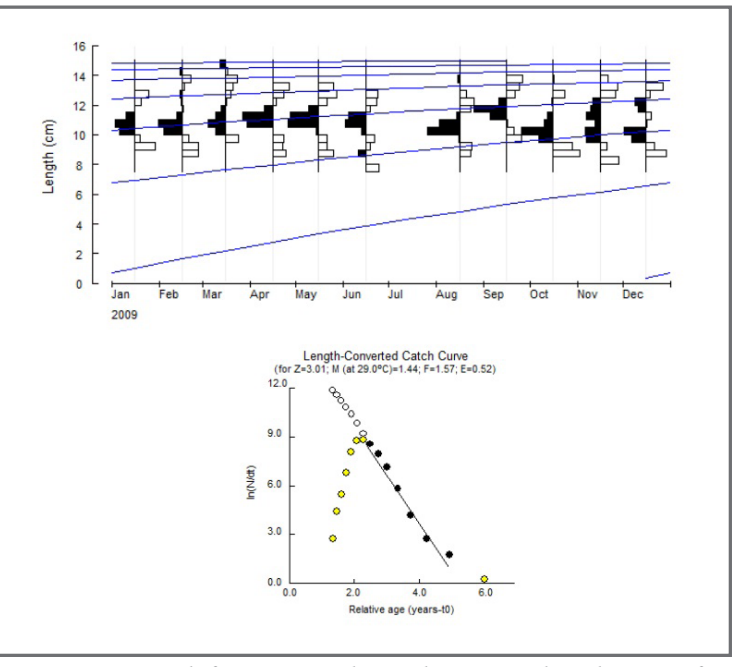

Figure 8. Length frequency and Length-converted catch curve of Sardinella tawili in Taal Lake from 2009.

indigenous fishes of the lake.

\section{Tawilis population}

The length frequency data of tawilis caught by combined gill net and beach seine from 2009 and 2011 has an estimated range of $\mathrm{L}_{\infty}$ from 15.40 to 16.36 (Table 7). The $\mathrm{L}_{\infty}$ is the mean length of the fish in the population that will be reached if they grow indefinitely. The $\mathrm{K}$ value obtained ranged from 0.53 to 0.73 . It is the rate of dimension time at which $\mathrm{L}_{\infty}$ is approached.

The total mortality (Z) obtained ranged from 3.01 to 5.03 , natural mortality $(\mathrm{M})$ from 1.44 to 1.75 and fishing mortality (F) from 1.57 to 3.28. The exploitation rate (E) obtained ranged from 0.52 to 0.65 . The high fishing mortality and exploitation rates imply unsustainable fishing practice (Figures 8-10).

\section{D I S C U S S I O N}

The assessment of fisheries in Taal Lake revealed a continued decline in fish harvest in the open waters. The decline in harvest may be attributed to unsustainable

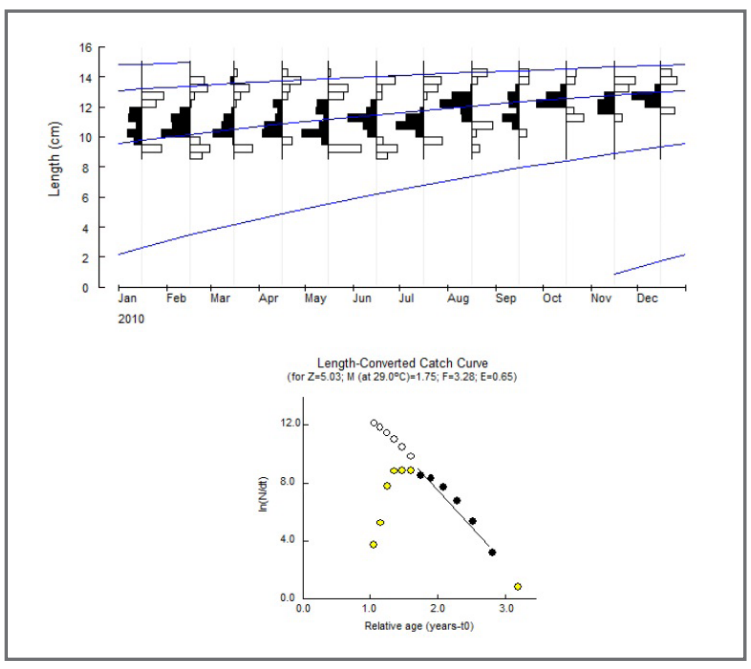

Figure 9 .Length frequency and Length-converted catch curve of Sardinella tawili in Taal Lake from 2010.

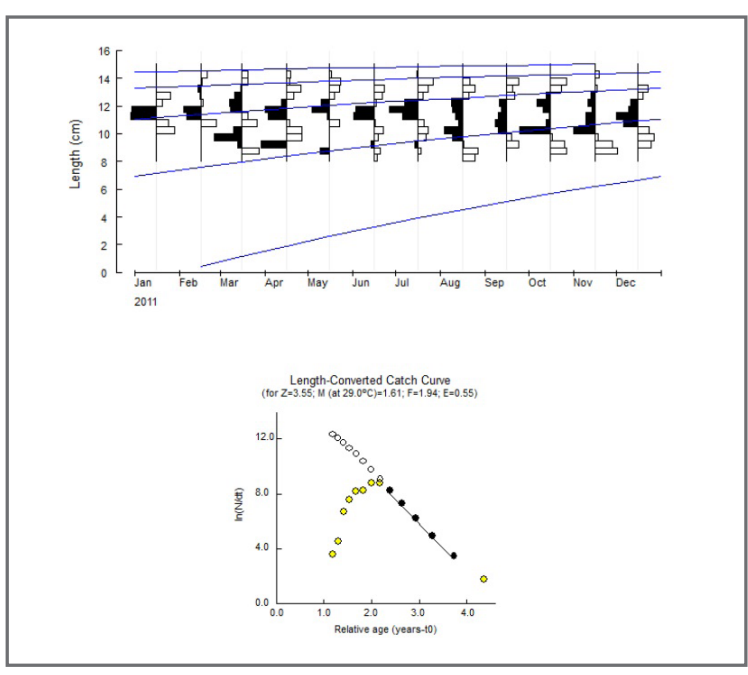

Figure 10. Length frequency and Length-converted catch curve of Sardinella tawili in Taal Lake from 2011.

fishing practice and proliferation of aquaculture activities. The operation of the three active gear such as the beach seine, motorized push net, and ring net worsened the condition of the open water fisheries. 
The growing number of aquaculture activities in the lake also contributed to the declining population and displacement of indigenous fishes as well as introduction of more aggressive aliens species. These alien species may become invasive and disrupt the ecological balance of the lake. The continued operation of the active gear and the prevalence of introduced species reflect the laxity in the implementation of fishery laws and ordinances. To address the issue, Protected Area Management Board (PAMB) and Taal Lake Task Force should strictly implement the Unified Rules and Regulations for Fisheries (URRF) under the TVPL management plan. Specifically, on the establishment of fish sanctuary area, prohibiting the introduction of alien species in the lake, banning the operation of active gear, mesh size regulation of fishing gear, and support to R \& D programs are necessary for the conservation and management of indigenous fishes in the lake.

\section{A C K N O W LED GEMEN T}

We would like to express our gratitude to the following for their big contribution to this research project: National Fisheries Research and Development Institute, for funding the Project; Local Government Units (LGUs) for allowing us to conduct the survey in their respective municipalities; the fishermen and other respondents for sharing their knowledge and time; and our enumerators for their hard work and reliable survey data.

\section{R E F E R E N C E S}

Aypa SM, Galicia AM Jr., Lapasaran ES. 1991. A contribution to the biology of Herengula tawilis in Taal Lake, Batangas. Bureau of Fisheries and Aquatic Resources, Project Completion Report to the DA of Agricultural Research, 12 pp., 2 tables, 3 figures.

Castillo BB, Castillo AS, Gonzales CL. 1975. Tawilis fishery resources investigation of Taal Lake. Report to the Bureau of Fisheries and Aquatic Resources, p. 16. FishBase. 2012. http://www.fishbase.org/

Hargrove TR. 1991. The mysteries of Taal. A Philippine volcano and lake, her sea life and lost towns. BookPublishing, Manila, p. 204.

Herre AW. 1927. Four new fishes from Lake Taal (Bombon). Philippine Journal of Science 34(3): 273-278.
Mercene EC. 1997. Freshwater fishes of the Philippines. Proc. First National Symposium on Aquatic Biology R\&D PCAMRD;No.20.

Mercene-Mutia MT. 2001. Assessment of local government's implementation of open access policy in Taal Lake, Philippines: effects on lake conservation and management, pp 123-132. In CB Santiago, ML Cuvin-Aralar and ZU Basiao (eds). Conservation and Ecological Management of Philippine Lakes in Relation to Fisheries and Aquaculture. SEAFDEC, Iloilo; PCAMRD, Los Banos, Laguna and BFAR, Quzon City, Philippines. p. 187.

Mutia MT, Magistrado ML, Muyot MC. 2004. Status of Sardinella tawilis in Taal Lake, Philippines. Proceedings of the $8^{\text {th }}$ Zonal Center II Research and Development Review. De La Salle University, Taft, Manila. p. 14.

Mutia MT, Muyot MC, Torres FB, Faminialagao CM. 2011. Seasonality, Abundance and Biology of Tawilis (Sardinella tawilis) in Taal Lake, Batangas. $2^{\text {nd }}$ National Congress on Philippine Lakes. SEARCA, UP Los Banos, Laguna. April 27-29, 2011.

Presidential Commission on Tagaytay-Taal. 1993. Agriculture and fisheries program, Vol. 1, p. 2124 and 2.1.2 Fisheries, Vol. 4, p. 30-72 and 101110. In Tagaytay-Taal Integrated Master Plan, 20 Year Timeframe 1994-2014, PCTT, Department of Tourism, Manila, Philippines.

Rosana MR, et al. 2006. Parachromis managuensis (Gunbther, 1867) in Taal Lake. Philippine Journal of Environmental Science and Management 9(2): 1-19.

UPLB Foundation, Inc. 1996. Rapid resource appraisal of Taal Lake. Terminal report submitted to Bureau of Fisheries and Aquatic Resources.

Villadolid DV. 1937. The fisheries of Taal Lake, Pansipit River and Balayan Bay, Batangas Province, Luzon. Philip. J. Sci. 63(2): 191-225

Villanueva LS, Luistro AP, Calabig CS. 1996. Assessment of Taal Lake capture fisheries with emphasis on the exploitation of Herengula tawilis. STIARCH. 